\title{
K problematike analýzy literárneho diela
}

СЕМЫКИНА, Е.Н., ШИРИНА, Е. А.: Художественное произведение как объект литературоведческого анализа. Белгород: ИД «Белгород», 2018. 196 с. ISBN 978-5-9571-2566-2.

Správne pochopenie, tj. výklad a analýza literárneho diela, je neustále jedným z problémov pri interpretácií literárnych diel, s ktorým sa stretávame pri vyučovaní literatúry. Dôvodom je nesprávny prístup študentov k analýze literárneho textu, ktorý má za následok zlú interpretáciu a nepochopenie autorovho odkazu v diele.

Tento problém súčasným filológom neuniká. Na základe práce so študentmi Belgorodskej univerzity (Rusko) i žiakmi Belgorodskej oblasti a skúseností z praxe v oblasti analýzy literárneho diela bola vydaná publikácia E. N. Semykinovej a E. A. Širinovej s názvom Художественное произведение как объект литературоведческого анализа.

Autorky si v danej publikácii určili za ciel’ prehĺbit’ doterajšie poznatky žiakov/študentov o metodike literárnej analýzy, rozšírit ich analytické i interpretačné schopnosti a pri práci s umeleckým textom formovat nový typ vzt’ahu žiaka a učitela založený na rozvoji žiakových analytických schopností a na pozícii učitela ako odborného poradcu, ktorý neohraničuje žiakove interpretácie, ale usmerňuje ich. Autorky usilujú o to, aby predkladaná publikácia dala predovšetkým študentom stredných škôl ešte pred štúdiom na vysokej škole možnost’ oboznámit’ sa s vhodným postupom analýzy literárneho textu a zároveň im pomohla rozvíjat interpretačné schopnosti a kritické myslenie. Preto autorky zvolili jednoduchý a zrozumitelný štýl výkladu, ktorý ale danú problematiku nezjednoduchšuje. Zvýšená pozornost̉ je venovaná metodologickým postupom, ktoré majú viest̉ žiaka k správnej interpretácii literárneho diela.

Kladne hodnotíme snahu autoriek naučit záujemcu o interpretáciu formulovat tzv. „text o texte“ ako formu písomnej analýzy diela. Predkladajú postupnost’ etáp a krokov, a to charakterizovaných ako počiatočné zoznámenie sa s textom - analytická práca - napísanie „textu o texte“. V publikácii niekolkokrát upozorňujú na nemožnost’ existencie jednej univerzálnej schémy na vypracovanie analýzy rôznych literárnych diel. Autorkami predkladaná schéma „textu o texte“ je formulovaná ako pomocný aparát, o ktorý sa žiak môže pri analýze opierat', dáva mu istý základ a vytvára priestor pre jeho d’alšiu samostatnú prácu.

Publikácia je rozdelená do siedmych kapitol. Od počiatočných teoretických informácií sa postupne prechádza k praktickým príkladom. Prvé dve teoretické kapitoly 
sa zameriavajú na základy analytickej práce s textom. Tretia kapitola má príznačný názov Литературоведческая азбука для начинающих. Práve v tejto kapitole sú interpretujúci postavení na pomyselnú „štartovaciu čiaru“, od ktorej si (opät) osvojujú základné vedomosti nutné $\mathrm{k}$ práci s literárnym dielom a jeho analýzou. $\mathrm{V}$ tejto kapitole sa poukazuje na metodické postupy, porovnávajú sa rozdiely opisu napr. konceptu jesene $\mathrm{v}$ umeleckej a náučnej literatúre. Za pozitívum tejto kapitoly považujeme práve „opakovanie“ definící literárnych trópov a figúr spolu s praktickými príkladmi a snahu autoriek poukazovat na typické chyby pri analyzovaní diela. V nasledujúcej kapitole je pozornost̉ zameraná na význam literárneho kontextu pri analýze a na dôležitost̉ poznania širších súvislostí - doby, spoločenskej situácie atd’.

Piata kapitola poukazuje na význam dobrej prípravy pred samotným zostavovaním písomnej analýzy a možné varianty žiakovho postupu pri práci s analyzovaným textom. Posledné dve kapitoly publikácie zoznamujú čitatela s konkrétnymi analýzami, vrátane komentárov $\mathrm{k}$ týmto prácam. Ako príklady sú tu uvádzané analýzy lyrických a epických literárnych diel od 19. storočia po súčasnost', napríklad analýza zameraná na koncept добра и зла v poviedke T. N. Tolstej Соня, alebo analýza básne A. A. Achmatovovej Песня последней встречи. Ide o praktické ukážky, ktoré študent nemá považovat' za vzorové, ale majú/môžu mu slúžit ako názorná pomôcka. Autorky tak vhodne prepojujú teóriu s praxou, čo ocení najmä samouk, ktorý nemá možnost̉ vidiet praktickú ukážku analýzy na hodine.

Celkovo je publikácia obsahovo dobre spracovaná a svojim zameraním na hlbšiu analýzu literárnych textov velmi aktuálna $\mathrm{v}$ dnešných podmienkach, ked’ sa v školskej praxi často stretávame iba s povrchovou analýzou literárnych diel. Autorky poodhalujú problémové miesta literárnej analýzy zrozumitelnou formou a na základe vlastných praktických skúseností posilňujú vzt̉ah učitel - žiak, v ktorom je učitel žiakovi mentorom a skúsenejším kolegom a vytvára priestor pre jeho samostatnú prácu s literárnym textom. Preto môžeme význam danej publikácie vidiet nielen pre žiaka či študenta vysokej školy, ale aj učitela literatúry. Prínosom pre slovenské prostredie by bol preklad recenzovanej publikácie, prípadne, keby sa objavila publikácia podobného typu a zamerania.

Igor Cintula

\section{Literatúra:}

SEMYKINA, Je. N., ŠIRINA, Je. A.: Chudožestvennoje proizvedenije kak ob”jekt literaturovedčeskogo analiza. Belgorod: ID «Belgorod», 2018. 196 s. ISBN 978-5-9571-2566-2.

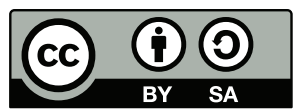

This work can be used in accordance with the Creative Commons BY-SA 4.0 International license terms and conditions (<https://creativecommons.org/licenses/by-sa/4.0/legalcode>). This does not apply to works or elements (such as images or photographs) that are used in the work under a contractual license or exception or limitation to relevant rights. 